\title{
Desenvolvimento infantil, educação e primeira infância: Histórias infantis como alternativa pedagógica
}

\author{
Child development, education and first childhood: Child stories as a pedagogical alternative \\ Desarrollo infantil, educación y primera infancia: Los cuentos infantiles como alternativa \\ pedagógica
}

Recebido: 21/05/2021 | Revisado: 29/05/2021 | Aceito: 31/05/2021 | Publicado: 13/06/2021

Herika de Souza Machado ${ }^{1}$

ORCID: https://orcid.org/0000-0001-5514-0455 Universidade Paulista, Brasi

E-mail: herykamachado@gmail.com

Suélen Maria Pereira da Silva ${ }^{1}$

ORCID: https://orcid.org/0000-0001-9699-3681 Universidade Paulista, Brasil

E-mail: soldeaguia@hotmail.com José Eduardo Silva ${ }^{2}$

ORCID: https://orcid.org/0000-0002-8483-0305 Universidade Paulista, Brasil

E-mail: profeduardosilva3@gmail.com

\begin{abstract}
Resumo
As histórias infantis são importantes ferramentas para o desenvolvimento cognitivo, formação da identidade e valores, além de fortalecer o vínculo familiar, colaborando em benefícios relacionados ao desenvolvimento da criança. Objetivou-se refletir sobre as pesquisas acadêmicas que abordam a importância de práticas pedagógicas no desenvolvimento da criança com a ludicidade por meio do conto de histórias infantis, considerando seu impacto emocional e cognitivo. Utilizou-se o método do tipo pesquisa bibliográfica, com enfoque no Estado da Arte e abordagens, qualitativa e quantitativa. Cuja análise dos dados buscou refletir sobre a produção acadêmica acerca da importância da contação de história a partir da primeira infância, como instrumento para o planejamento das práticas pedagógicas, agregando valor e significação para a aprendizagem da criança. Evidenciando, ainda, a importância da família em parceria com a escola nesse processo de construção e estímulo para a prática da leitura. Os resultados demonstram tendências crescentes em quantidades de publicações, bem como constatou-se que o método utilizado oportuniza a identificação de possibilidades com efetivos resultados de aprendizagem mediante a contação de histórias. Conclui-se que aspectos motor, emocional e cognitivo, são construídos com práticas pedagógicas que se utilizam da ludicidade. Deste modo, as histórias infantis funcionam como guia para as práticas pedagógicas através da ludicidade em atividades proporcionadas ao desenvolvimento de competências das crianças.
\end{abstract}

Palavras-chave: Educação infantil; Contos; Literatura infantil; Ludicidade; Práticas.

\begin{abstract}
Children's stories are important tools for cognitive development, formation of identity and values, in addition to strengthening the family bond, contributing to benefits related to the child's development. The objective was to reflect on academic research that addresses the importance of pedagogical practices in the development of children with playfulness through children's storytelling, considering their emotional and cognitive impact. The bibliographic research method was used, with a focus on the State of the Art and approaches, qualitative and quantitative. Whose analysis of the data sought to reflect on academic production about the importance of storytelling from early childhood, as an instrument for planning pedagogical practices, adding value and meaning to the child's learning. Also evidencing the importance of the family in partnership with the school in this process of construction and encouragement for the practice of reading. The results demonstrate growing trends in quantities of publications, as well as it was found that the method used makes it possible to identify possibilities with effective learning results through storytelling. It is concluded that motor, emotional and cognitive aspects are built with pedagogical practices that use playfulness. In this way, children's stories serve as a guide for pedagogical practices through playfulness in activities provided for the development of children's skills.
\end{abstract}

Keywords: Child education; Tales; Children's literature; Playfulness; Practices.

\footnotetext{
${ }^{1}$ Graduação em Licenciatura em Pedagogia pela Universidade Paulista - UNIP, Recife - Pernambuco.

${ }^{2}$ Professor e Orientador do Curso de Licenciatura em Pedagogia pela Universidade Paulista - UNIP, Recife - Pernambuco.
} 


\begin{abstract}
Resumen
Los cuentos infantiles son herramientas importantes para el desarrollo cognitivo, la formación de identidad y valores, además de fortalecer el vínculo familiar, contribuyendo a los beneficios relacionados con el desarrollo del niño. El objetivo fue reflexionar sobre la investigación académica que aborda la importancia de las prácticas pedagógicas en el desarrollo de los niños con alegría a través del relato infantil, considerando su impacto emocional y cognitivo. Se utilizó el método de investigación bibliográfica, con enfoque en el estado del arte y enfoques, cualitativos y cuantitativos. Cuyo análisis de los datos buscó reflexionar sobre la producción académica sobre la importancia de la narración desde la primera infancia, como instrumento para planificar las prácticas pedagógicas, agregando valor y significado al aprendizaje del niño. Evidenciando también la importancia de la familia en alianza con la escuela en este proceso de construcción y estímulo para la práctica de la lectura. Los resultados evidencian tendencias crecientes en cantidad de publicaciones, así como se encontró que el método utilizado permite identificar posibilidades con resultados de aprendizaje efectivos a través del storytelling. Se concluye que los aspectos motores, emocionales y cognitivos se construyen con prácticas pedagógicas que utilizan la alegría. De esta manera, los cuentos infantiles sirven de guía para las prácticas pedagógicas a través del juego lúdico en actividades previstas para el desarrollo de las habilidades de los niños.
\end{abstract}

Palabras clave: Educación infantil; Cuentos; Literatura infantil; Alegría; Prácticas.

\title{
1. Introdução
}

As histórias infantis sob o prisma do construtivismo, são muito importantes para a construção de memórias afetivas, independente da cultura, povo ou região. Tendo como finalidades: o desenvolvimento cognitivo, a formação da identidade e de valores, além de fortalecer o vínculo familiar, fazendo parte de nossas vidas desde cedo.

A primeira infância é o período mais importante do desenvolvimento humano e é na educação infantil, fase inicial da educação básica, que a criança começa o processo de letramento através do contato com a literatura infantil e todas as práticas interdisciplinares que se relacionam com outros meios de expressões como a música, a imagem, e o movimento, construindo conhecimentos ao longo do desenvolvimento cognitivo e emocional (Silva, 2017). Teóricos construtivistas como Piaget, Vygotsky e Wallon fornecem embasamentos suficiente para a utilização das histórias infantis como recurso metodológico nas práticas pedagógicas escolares, agregando valorização e significação para a aprendizagem da criança.

A linguagem está na natureza do homem, mesmo antes do nascimento, estudos demonstram que o bebê já traz ao nascer a competência de discriminar a voz materna, além de responder-lhe de modo significativo. Por volta do quarto mês de gestação, a capacidade auditiva do feto encontra-se organizada e capaz de perceber os pais conversarem com ele. Ao decorrer deste desenvolvimento, os pais costumam contar muitas histórias, lendas, contos ou fábulas e à medida que são contadas e recontadas marcam significativamente suas memórias.

Diante do exposto, Gatti (2019) reitera que a comunicação entre o bebê, seus pais e familiares é importante para a construção do processo de significação, pois a considera como um sujeito de fala, estabelecendo a comunicação entre eles a partir das interpretações dos balbucios, movimentos corporais ou até mesmo para onde o bebê direciona sua visão, configurando a comunicação estabelecida entre as partes.

Assim, as histórias infantis contribuem para registrar no subconsciente das crianças, milhares de emoções que as capacitam individual e socialmente. O universo da ludicidade traz nas histórias infantis o incentivo e o gosto pela leitura. É a partir desse contato literário com suas diversas formas, que se estimula à vontade em descobrir novas histórias e assim tornar leitores ativos (Barone, 2020).

Atualmente, as escolas possuem ricos acervos de livros de histórias infantis, como ferramenta para o desenvolvimento infantil, dado que a década de 70 foi o marco das obras literárias infantis com o propósito de auxiliar o desenvolvimento cognitivo durante o processo voltado ao ensino, aprendizagem e alfabetização, fruto do movimento Escola Nova, que tinha como um dos objetivos a diminuição do alto índice de analfabetismo. Criando condições para o aparecimento de autores como Monteiro Lobato, que escrevia segundo a realidade brasileira (Porto, 2019). 
A leitura mediada, de acordo com Pelisson e Rodriguez (2017) é compreendida por ser uma atividade sistemática de construção educativa em conjunto, onde o professor abre espaço para que os alunos reflitam sobre as histórias narradas, construindo assim reproduções da realidade. Assim sendo, o contato com as histórias infantis desde os primeiros meses de vida, colabora para uma série de benefícios relacionados ao desenvolvimento da criança, tais como: aguçar a imaginação, favorecer as conexões neurais do cérebro, otimizar a audição, estimular a visão de mundo real, conhecer o que está em sua volta, tornar-se participante ativo de um processo individual e coletivo de ensino-aprendizagem, além do crescimento positivo intelectual e social. As histórias infantis através de sua ludicidade, contribuem para formação do indivíduo, atuando no desenvolvimento comunicativo e interacional.

Silva (2017) refere-se a literatura infantil com caminho vasto que abre oportunidades para imaginação, que incentiva a prática de uma leitura prazerosa, além de aumentar a proficiência tanto da escrita quanto da leitura, contribuindo para a formação de leitores pensantes e críticos. Em que a intervenção da literatura proporciona a transformação da criança em sujeito ativo, responsável pôr sua própria aprendizagem, compreendendo o contexto em que vive e modificando-o conforme sua necessidade.

O método de contar e recontar histórias, é um processo muito importante para o desenvolvimento da linguagem oral, pois, imerso ao contexto lúdico a criança tende a desenvoltura para a articulação de ideias, comunicação, expressão do pensamento, apresentando assim um discurso mais completo com um vocabulário melhor elaborado. É válido citar também que essa interação entre o adulto e a criança, em que as histórias são dinamizadas tornam esses momentos mais prazerosos e ativos para as crianças, estimulando-as sempre em querer estar em contato com esse mundo do faz de conta (Pimentel, 2017).

As novas gerações já nascem em meio a tecnologia e o acesso aos dispositivos tecnológicos midiáticos facilita o contato com acervo enorme de conteúdo com histórias, contos e fábulas, ou seja, antes mesmo da criança entrar na escola, os pais já iniciam esse processo de contato com o mundo do faz de conta, que na escola ocorre o direcionamento eficaz dessa ferramenta para que a criança seja provocada em outros aspectos. A inserção de recursos tecnológicos no ambiente escolar é de válido, tanto para quem ensina, como para quem aprende e, se bem utilizados contribuem com eficácia ao desenvolvimento do aluno conferindo qualidade do ensino e aprendizagem (Souza, 2019).

De acordo com Bencke (2019) a utilização de tecnologias em bibliotecas escolares, caracteriza recurso importante para atrair os alunos de forma espontânea para o universo literário, visto que já possuem conhecimento prévio dentro das mídias digitais e dessa forma estimula-se o gosto pela leitura. Então, ofertar a literatura infantil a partir dos recursos tecnológicos, é também uma forma de inserir as crianças desde cedo em contato com diferentes suportes digitais, facilitadores de uma nova visão formadora de leitores competentes, capazes de transitar pelos diferentes gêneros textuais.

Contar histórias deve ser entendida como suporte didático para os professores e para os pais, que poderão se utilizar da prática para incentivar e desenvolver habilidades na produção da escrita, leitura, saber lidar com as crianças em relação às suas emoções, acompanhar melhor os currículos escolares, estimular o gosto pelo conhecimento, em querer aprender, se concentrar em ouvir e prestar atenção na narração, criar um imaginário que influencie positivamente no comportamento social e emocional.

Em vista disso, os momentos da contação de histórias enquanto recurso para as práticas pedagógicas, devem ser momentos de satisfação e sonhos para as crianças, possibilitando a vivência de cada sentimento despertado e a reflexão sobre as mensagens contidas nas histórias. O professor ao planejar a aula, deve considerar a interação com as crianças, respeitando a linguagem e o modo de vida delas, contribuindo para o desenvolvimento cognitivo e emocional por meio dessa cultura infantil entre o real e a fantasia (Borges \& Rehbein, 2020)

Neste sentido entende-se que as crianças necessitam do contato com os livros e com a leitura desde cedo. Para desenvolver esse contato precisa-se de suporte literário em que haja condições do professor efetuar em sala de aula leituras 
atraentes e aconchegantes onde as crianças possam usufruir das histórias e situações prazerosas de interação com a leitura (Pimentel, 2017; Queiroz, 2017; Silva, 2017 \& Oliveira, 2020).

Por fim, da Silva, Alencar e Bernardino (2017) consideram ser inevitável o poder que a contação de história tem sobre as pessoas, de provocar diversas reações e sentimentos, utilizando essa prática como recurso para formação de novos leitores ativos. Afirmam que estimula a imaginação, criatividade e a oralidade, além de trabalhar a concentração, contribuindo para um ser pensante e crítico o ajudando na formação da personalidade em meios social e afetivo.

Nesta pesquisa objetivou-se refletir sobre as pesquisas acadêmicas que abordam a importância de práticas pedagógicas no desenvolvimento da criança com a ludicidade por meio do conto de histórias infantis, considerando seu impacto emocional e cognitivo. Cujo problema de pesquisa buscou-se responder ao questionamento: como as histórias infantis podem contribuir para o desenvolvimento emocional e cognitivo a partir da primeira infância? Contudo, a pesquisa se faz pertinente e se justifica pela reflexão da literatura infantil, na perspectiva em resgatar o genuíno prazer do imaginário e da curiosidade infantil em sua compreensão de mundo através das histórias, conjuntamente com a construção de sua formação emocional e cognitiva.

Trata-se de uma pesquisa bibliográfica, de natureza quantitativa e qualitativa com enfoque em Estado da Arte, que visa ressaltar a importância da contação de histórias como um valioso recurso didático para professores e pais, como facilitadora da alfabetização, desenvolvimento intelectual, oral e social. A leitura além de ser um recurso para ensinar, é a própria essência do leitor, depende de uma linguagem clara, dinâmica e divertida, influenciando o prazer pela leitura e a solidificação de leitores ativos. Por fim, poder mostrar como as histórias interferem positivamente no desenvolvimento da criança, assim como as práticas da leitura fazem com que reconheça sua participação no seu próprio processo de ensinoaprendizagem.

\section{Contação de História: Breve Histórico}

Souza e Francisco (2017) conjecturam ao termo "contação de histórias" resultado da tradução da expressão cuentacuentos, advinda de países de língua castelhana e significa tanto o ato de contar histórias, quanto o próprio contador. A língua inglesa também apresenta o termo storytelling como ato, ou capacidade de se narrar um fato, ou história, seja ela de improviso ou planejada, podendo recorrer a diversas categorias de recursos.

A contação de histórias surgiu antes mesmo do homem aprender a escrever, foi a forma encontrada, em épocas passadas, para se estabelecer a comunicação oral. Em momentos atuais percebe-se que as histórias ultrapassam gerações podendo ser encontradas e relembradas nos livros, filmes televisivos ou pelo cinema e até mesmo nos jogos. A prática da contação de histórias surgiu desde os tempos remotos, um costume muito antigo da cultura humana há milhões de anos que se deu antes do desenvolvimento da escrita. Essa foi a forma que a humanidade encontrou para expressar e transmitir suas experiências de geração em geração. Os contos exprimem os sentidos da vida, transmitem valores passados de geração para geração (Silva, 2017).

Portanto, a contação de histórias é um instrumento utilizado como veículo para passar informações através do tempo, e resgatar qualidades necessárias para o desenvolvimento humano, e consiste em apresentar uma narrativa que parte de certa leitura de mundo, atendendo as necessidades de perpetuar um povo. Muito embora, Archangelo e Mendonça (2020) apresentarem fundamentos paradoxais sobre as transmissões das histórias, concordam que essa experiência possui relevância para o processo de internalização em meio a impermanência de experiências de vida do indivíduo. Nesse sentido, a relação estabelecida entre narrador e ouvinte propicia a interioridade e auxilia na construção do ser. 
Para Oliveira (2020) a história se transforma com o passar do tempo e é produto de sujeitos que eram espectadores que acontecia em seu universo. Através de suas conclusões, tanto eles levavam como traziam histórias para seu povo e assim transmitiam ensinamentos e conhecimentos.

Silva (2017) e Porto (2019) descrevem que não existiam obras literárias voltadas para o público infantil, pois não havia distinção entre adultos e crianças. A criança era vista como um adulto em miniatura e podemos observar essa igualdade entre adultos e crianças pela perspectiva de algumas telas que expressam em suas pinturas vestimentas iguais para ambos, confirmando o comportamento social de épocas anteriores a década de 70.

À medida que a sociedade evoluía, a visão sobre a criança progredia. A partir da ascensão burguesa, houve uma reestrutura no meio familiar, onde a criança passa a ter seu reconhecimento diferente do adulto. Como consequência, iniciou-se a construção social da infância e a produção de obras voltadas para as crianças, porém, com a finalidade de educá-las nos princípios que regiam aquela sociedade e ensinando-as os que era classificado como bem ou mal. Nesse ponto, inicia-se o processo de valorização da infância como fase da vida diferente das demais etapas da fase adulta, onde a criança passa a ter os cuidados devidos ao seu desenvolvimento. Em função desta visão, surgiu a necessidade de se criar uma literatura apropriada para o novo público, originando-se assim a Literatura Infantil (Do Rosário Abreu \& Gonçalves, 2020).

Queiroz (2017) descreve que foi Yvelines, conhecido como o Rei Sol, o maior dos reis absolutistas da França, século XVII, quem manifestou interesse para a criação de obras voltadas para o público infantil, constituindo-se assim a criação da Literatura infantil. As primeiras obras foram: as fábulas de La Fontaine (1668), os contos de Charles Perrault (1691), marcando o começo do universo literário voltado para as crianças. Analogamente, pode-se observar que a ascensão da burguesia foi o motivo desencadeador à criação da literatura infantil.

Constata-se em Rocha (2019) que as primeiras obras foram produzidas motivadas pelo crescimento industrial. O surgimento das indústrias e as ofertas de trabalhos, resultaram no êxodo rural e consequentemente no inchaço populacional das grandes cidades. Com o crescimento político e econômico, surgiu a necessidade de escolas para os filhos dos operários. Logo, a educação que era exclusiva da burguesia passou a ser de todos. Nesse momento histórico, a literatura infantil desenvolveu um papel muito importante na esfera escolar, transformando o entendimento sociocognitivo que a criança possuía, independentemente de sua calasse social.

Contudo, apesar de a educação ser direito da criança em todas as classes sociais, ainda assim existiam diferenças em como essa educação era transmitida. Baseado nos fatos históricos, aqui no Brasil, a educação infantil possuía duas formas para desenvolver suas crianças. As crianças a partir das classes média e principalmente alta, obtinham acesso a uma educação comprometida com seu desenvolvimento cognitivo e emocional, já as crianças das classes menos favorecidas, recebiam uma educação assistencialista, onde o objetivo principal era atender as necessidades de higiene, alimentação, cuidados e guarda (do Rosário Abreu \& Gonçalves, 2020).

No Brasil, a literatura surgiu na primeira metade do século XIX, porém foi no século XX que a literatura infantil teve sua devida importância para o público brasileiro. As versões dos clássicos europeus começaram a circular no país, porém não condizia com a realidade do povo brasileiro, a descrição de modo de vida na Idade Média do povo europeu que eram marcas nos contos, como também características geográficas completamente opostas do país (Queiroz, 2017).

Conforme Nascimento e Farias (2019) os contos de fada traziam em suas narrativas o retorno à Idade Média, com a descrição de salões de festas na Europa, frequentado pela elite e com personagens como reis, rainhas, príncipes, princesas, magos, bruxas, fadas duendes e outros elementos, foram os responsáveis pela expansão da literatura infantil decorrente de seu cenário perfeito para a magia da imaginação.

Anteriormente, quando não existia a distinção entre adultos e crianças, pode-se observar autores como os irmãos Grimm, que escreviam histórias para adultos, tiveram suas obras adaptadas para o público infantil, com a inserção de 
elementos dos contos de fada. As adaptações transformaram-se em clássicos que fazem sucesso até os dias atuais, como, por exemplo: João e Maria; Rapunzel; Branca de Neve e os 7 anões e $O$ príncipe sapo.

Porto (2019) retrata que em 1920 criaram-se condições para autores como Monteiro Lobato, que escrevia conforme a realidade brasileira, ascendesse a literatura infantil no Brasil com a valorização dos livros. Na década de 70 a literatura é retomada como fator importante para o desenvolvimento intelectual e cultural da criança fazendo com que a publicação de livros infantis atingisse números expressivos, com vista em assistir o desenvolvimento cognitivo durante o método dirigido para o ensino, aprendizagem e alfabetização.

Desta forma, a consciência sobre o valor que a literatura infantil possui na geração dos pequenos leitores, promove a inclusão na pauta de políticas públicas de educação e cultura, atenção e fomento a produção literária (Cademartori, 2017). Cabe lembrar que o século XX foi marcado por grandes acontecimentos, como a abolição da escravatura e, dada à realidade brasileira evidências retratam as primeiras representações do negro na literatura infantil, que se fortalece em olhar cultural nas obras de Monteiro Lobato (Farias, 2018). Construindo o sentimento de representatividade ao público anteriormente negligenciado, quando da imersão literária massivamente europeia.

Em concordância com Oliveira (2020) a história é uma cultura presente em nossos lares, pois se recorre a linguagens históricas passadas por gerações, a exemplo das canções de ninar quando cantaroladas para uma criança, ou quando contar um conto ou uma fábula e dessa maneira simples e ingênua a criança é inserida no universo da ludicidade.

Mendonça (2019) cita que a contação de história pode ser feita por qualquer pessoa que a aprecie, que tenha voz e memória, num movimento incessante de recriação. Enfatizando que contar história difere de ler uma história. Quando se conta uma história tem-se a possibilidade de improvisar, agregar elementos à narração e ler uma história significa ser fiel à linguagem apresentada pelo autor em sua obra. Dado que a literatura deve ser ofertada em todas as etapas da educação básica, como recurso para assimilar a linguagem e habilitar o indivíduo a interpretar e produzir textos. Por essa razão, diversos autores defendem o contato da literatura desde cedo, incumbindo a família e a escola, a responsabilidade de serem o elo entre as crianças e os livros (Moreira, 2018).

A família ou os professores quando conseguem gerir bem a contação de histórias, possibilitam à criança compreender a mensagem contida na história, oferecendo embasamento para seu entendimento, ou seja, a criança consegue enfrentar seus problemas de forma leve e criativa, buscando uma solução. À medida que a criança embarca no mundo de expectativas, capta as informações e as processa de forma consciente, conseguindo estabelecer voluntariamente uma interação mais confiante com o seu orador. Então, contar histórias de forma intencional ou não, pode ser uma ferramenta para a mediação do conhecimento, como também para tranquilizar, distrair, ensinar, além de desenvolver a oralização, socialização e emoção da criança, quando bem utilizadas (Queiroz, 2017; Silva, 2017; Porto, 2019).

Logo, pode-se dizer que as literaturas surgiram a partir do ato milenar de se contar histórias, bem antes da escrita, mostrando-se muito importante para o desenvolvimento emocional e cognitivo da criança. E a tradição de contar as histórias procedeu da necessidade do homem em se comunicar e passar sua cultura para as gerações seguintes. Portanto, seja no ambiente escolar ou familiar, a contação de histórias precisa ser praticada com maior regularidade para que a imaginação da criança através da ludicidade esteja sempre estimulada.

\subsection{Família, escola e literatura infantil: elementos essenciais ao desenvolvimento da leitura}

A leitura de literaturas é a chave para o indivíduo sair da marginalização, possibilitando o acesso a um nível cultural mais elevado, uma compreensão de realidade podendo intervir nos fatos e ter condição de vida melhor (Orlando, 2018). É importante que o desenvolvimento da leitura se inicie na primeira infância, principalmente, através de seus pais, pois o contato 
precoce com obras literárias infantis estabelece uma relação de prazer entre a criança e o hábito de ler (Neres \& Lacerda, 2017).

No momento que a criança nasce, já possui a competência de ouvir e emitir vários sons, apresentando assim, sua forma de se comunicar. Antes do seu ingresso na escola carrega em si, uma construção cultural e social através de sua família, através de contações de histórias e do convívio social (Fagundes, 2018). Inclusive, quando as crianças recebem orientação e ajuda de seus pais desde o início de seu nascimento e segundo Fagundes (2018) seu conhecimento recebe significado importante ao bom desempenho na escola. Nesse sentido, a atribuição da família é essencial para proporcionar o desenvolvimento da leitura de forma relevante.

Schneider, Martins e da Silva (2021) observam que as crianças são inquietas por natureza, ávidas por descobrirem o mundo onde estão inseridas, demonstrando interesse e curiosidade pelo seu entorno. Interesse esse, que viabiliza a relação delas com os adultos e o direcionamento para o entendimento. Nota-se que boa parte das crianças possuem oportunidade de terem contato com o livro bem cedo. Atitude bastante válida por parte de quem as oferece os livros, pois, evidencia-se a curiosidade pelo novo, em que as cores vibrantes dos desenhos que ilustram os livros infantis e os formatos diferentes de livros, despertam ainda mais a curiosidade da criança (Steiner et al., 2018).

Barone (2020) menciona que a própria Sociedade Brasileira de Pediatria indique um livro, recomenda aos pais, professores e demais responsáveis, que ler, cantar, conversar e fazer rimas para as crianças em sua primeira infância, favorece ao desenvolvimento psíquico. Por este motivo, a leitura para a criança deve ser iniciada desde quando bebê e continue ao longo de sua infância.

A leitura está além do ato de ensinar a escrever e a falar, pois antes mesmo de aprender a ler e a escrever, a criança aprende a fazer uma leitura do mundo que a rodeia e de coisas do seu cotidiano através das histórias. Assim sendo, a leitura é imprescindível no processo de aprendizagem, pois contribui para despertar e desenvolver o raciocínio lógico e a criatividade infantil (da Silva Elias, da Silva \& Coutinho, 2019).

Não obstante, destacar em Oliveira (2021) que a literatura infantil seja inserida no processo ensino-aprendizagem, com a finalidade de despertar nas crianças, o gosto pela leitura, por meio do contato diário, prazeroso, divertido e signific ativo, associado à criatividade e à imaginação, utilizado pelos professores como recurso para a formação de crianças leitoras. Desta forma, a escola apresenta-se como local propício ao planejamento de atividades didáticas, que possibilitam ao aluno a construção do conhecimento, além de ampliar sua criatividade, imaginação, afetividade, utilizando-se da literatura infantil como meio para acesso entre diversas linguagens (Weissheimer \& Montoito, 2020).

O letramento tem seu início na educação infantil, fase em que o professor apresenta grande variedade de textos, gêneros e tipos de livros sensoriais, para que a criança dê significado a seu processo de desenvolvimento cognitivo, através de erros na tentativa de acertos. Ademais, a criança quando se torna leitora ao aprender a ler, é consequência das conexões estabelecidas entre o agrupamento de sentidos por ela constituído e o agrupamento de sentidos que formam suas experiências de vida (de Marco, 2017).

Segundo Flôres e Gabriel (2020) os pais são os primeiros professores das crianças e o grau de literacia que possuem constitui em fator determinante para o desenvolvimento do gosto pela leitura na criança, ou seja, os pais que já possuem gosto pela leitura, frequentam livrarias ou bibliotecas, serão espelhos para seus filhos, pois nada adiantará se o pai encher o filho de livros, e não tem hábito de ler. Certamente, da mesma forma que a criança antes mesmo de falar desenvolve sua capacidade linguística, ela também antes de ler desenvolve sua capacidade leitora a medida em que é posta em contato com o universo literário.

Além disso, a leitura compartilhada, é um momento de envolvimento entre o adulto e a criança, onde desfrutam do mesmo instante de entusiasmo, dividindo a atenção para observarem o livro, ou a tela de um dispositivo tecnológico, para 
juntos poderem ouvir a história, apreciar as imagens apresentadas, imaginarem as personagens e as situações evocadas da narrativa e discutirem sobre as ideias que vão surgindo ao longo da interação com o texto.

A leitura compartilhada é uma atividade simples e intuitiva, mas também pode ser planejada de modo que se aproveite mais o enredo da história, uma vez ser capaz de integrar um sistema complexo de relações sociocognitivas, como o direcionamento da atenção, da intencionalidade, da perspectiva assumida a partir do uso da linguagem, dentre outros aspectos, ou seja, impacta no desenvolvimento linguístico e cognitivo da criança, preparando-a para ler e escrever com autonomia e confiança. Para o adulto, a leitura compartilhada favorece na consolidação de laços afetivos com seus filhos (Flôres \& Gabriel, 2020).

Consequentemente, quando uma criança tem a oportunidade de ouvir ou até mesmo de ler uma história, começa a desenvolver habilidades como: questionar; comentar; partilhar, criando uma conversa que não fica limitada apenas ao contexto da história, mas que evolui conforme os estímulos que a própria história lhe oferece, derivando desse modo um diálogo, um entrosamento social entre leitor e ouvinte e entre o livro e a criança (Lima, 2019).

Atualmente, é primordial que o indivíduo tenha domínio completo sobre o código escrito, ou seja, que ele saiba ler, escrever e interpretar. Por este motivo, a sociedade contemporânea expressa essa preocupação social em formar leitores nas escolas, nos ambientes formais de aprendizagem e no seio familiar, combatendo assim a falta de hábitos de leitura. (Balça; Azevedo \& Barros, 2017).

De acordo com Pimentel (2017) a leitura de histórias é uma realidade cotidiana na educação infantil, mesmo que as crianças não saibam ler, elas irão desenvolver comportamentos e atitudes características de um leitor, com base nessa rotina de leitura. Quando a criança não sabe ler, faz a leitura dos livros através das ilustrações, por isso, a escolha dos livros infantis não deve ser feita de forma aleatória, deve seguir critérios como a faixa etária para que a criança ao manusear o livro ou ouvir a contação da história, consiga compreender o que o narrador transmitir.

Dito isto, é de responsabilidade do professor ao fazer seu planejamento, entender as necessidades de sua turma para poder escolher as obras literárias mais adequadas e usá-las de forma eficaz, em que possa auxiliá-lo como suporte e recurso numa futura ficha de desenvolvimento do aluno, onde ele poderá identificar de forma individualizada determinadas dificuldades dos alunos como saber ouvir ou reproduzir o que ouve, podendo sanar as dificuldades ao longo do planejamento pedagógico (Porto, 2019).

Conforme Nascimento e Farias (2019) as ilustrações são essenciais para chamar a atenção das crianças e despertar o gosto de ter um livro em suas mãos, nem que seja para folhear as gravuras nele encontradas. Por este motivo, que a escolha dos livros infantis, pelos pais e pela escola precisa de cuidados necessários, não escolhendo os livros de forma aleatória como se fossem meros passatempos. Os livros ajudam ao aprendizado cognitivo da criança, sem mencionar que, com as diferentes ilustrações, as crianças passam da imaginação para uma imagem visual daquilo que é contado.

Os educadores ao organizarem suas atividades envolvendo a leitura, precisam atentar para a faixa etária de seus alunos, seu círculo social e grau de entendimento, contribuindo com a valorização do conhecimento de mundo (Silva, 2017). Motivo pelo qual, a atividade pedagógica não pode limitar-se apenas a ensinar a ler, é fundamental a motivação para a criação do hábito da leitura pelo aluno.

Porém, confere-se que a dificuldade encontrada pelos educadores, em desenvolver o bom leitor, está localizada nas classes sociais menos favorecidas, pois as realidades das crianças são bem contrastantes, principalmente pelo fato de muitas delas terem pais analfabetos ou até mesmo semianalfabetos. Dessa forma, a escola torna-se o único lugar em que essas crianças possuem acesso ao universo literário (Vilela; Mariani Braz \& Silva, 2019). 
O professor carrega em si uma missão muito importante ao apresentar a literatura infantil para seus alunos, pois está em sua responsabilidade, transparecer para seus alunos, satisfação ao ler ou contar uma história, para que assim, eles também queiram ter esse mesmo prazer e despertando para a leitura (Steiner et al, 2018).

Por fim, a família e a escola devem incentivar desde cedo o hábito da leitura, promovendo para a criança oportunidades de contato com os livros, onde possa manipular livros tanto de forma livre quanto planejada para que a partir daí se familiarizem com sua forma e linguagem. A prática da leitura é libertadora para o desenvolvimento do indivíduo na totalidade, pois o seu domínio oportuniza a busca constante por conhecimentos, além de ser um instrumento de conscientização e mudança das estruturas de comunicação e crítica.

\subsection{Práticas pedagógicas na primeira infância}

O âmbito infantil é envolvido pela fantasia das histórias, dos contos de fada, das animações de filmes e desenhos infantis que permeiam a imaginação das crianças, contribuindo para construção de uma cultura a partir do imaginário de forma significativa. A ludicidade na educação infantil faz parte do cotidiano dos educandos e contempla as práticas pedagógicas de forma integral nos planejamentos dos professores (Borges \& Rehbein, 2020).

O ponto de vista construtivista reporta a educação como propulsora para o desenvolvimento infantil, onde a escola possibilita o caminho para o processo de ensino e aprendizagem considerando essenciais questões culturais de seus alunos. A metodologia construtivista possibilita ao professor trabalhar com o aluno de forma que desenvolva autonomamente e construa seu próprio conhecimento (Galvão da Silva, 2020). Dado que no universo escolar, a atribuição principal do professor é ensinar. Essa praxe presume ser o responsável por oferecer as melhores condições e os melhores métodos de aprendizagens para seus alunos, especialmente, às crianças da educação infantil (De Marco, 2020).

Nessa perspectiva, Schneider, Martins e da Silva (2021) reafirmam sobre o valor da criança como ator principal da função didática e enfatizam que o planejamento do professor deve considerar a investigação pedagógica e ter como base o cotidiano escolar das crianças, como seus questionamentos, suas falas, suas conquistas e assim por diante.

A literatura infantil é uma ferramenta pedagógica fundamental para o desenvolvimento de crianças leitoras. Na primeira infância favorece de forma construtivista o desenvolvimento dos níveis superiores de inteligência infantil, compreendendo as competências linguísticas, estéticas e culturais além de viabilizar adequações e significados presentes nos diversos tipos de textos literários (de Marco, 2020).

Segundo Brandão e De Souza Rosa (2017) os professores ao planejarem as práticas pedagógicas da educação básica devem sempre considerar o interesse e a necessidade da criança. Existem várias formas de se trabalhar a linguagem escrita na educação infantil que é através dos outros tipos de linguagens (plástica, corporal, musical, de faz de conta) que dará o suporte necessário para o desenvolvimento das crianças à medida que se expressam.

Por volta dos anos 60, o entendimento era de que a criança só era capaz de aprender a ler e a escrever entre 6 e 7 anos. O trabalho realizado naquela época na educação infantil via-se voltado para o desenvolvimento de habilidades de coordenação viso-motora, memória visual e auditiva, orientação espacial, articulação adequada de palavras, certo grau de atenção e concentração, boa alimentação, entre outros, que eram tidos como habilidades prévias para quando atingirem a idade ideal estivessem prontas para o início do processo de alfabetização. Essas práticas ao longo dos anos desencadeou impacto na orientação de políticas públicas nas décadas de 70 e 80 a respeito do ensino na educação infantil em todo o país (Brandão \& de Souza Rosa, 2017).

De acordo com De Marco (2020) os professores da educação infantil são mediadores essenciais na promoção da leitura para as crianças. Essa mediação provoca a organização intencional das atividades pedagógicas, necessárias em estimular 
novas vontades leitoras na criança, pois, apenas quando o professor direciona efetivamente a atividade, a criança compreende seu significado e desenvolve sua visão de mundo.

Importante considerar que brincando as crianças aprendem, através da ludicidade apresentada em cada vivência na sala de aula. Nas salas de educação infantil, pode-se observar várias atividades destinadas em estimular o desenvolvimento da linguagem oral como rodas de conversa, hora da contação de histórias, musicalização no bom dia, entre outras práticas, que visam melhorar as habilidades orais das crianças. Logo, o ambiente escolar possui as bases necessárias à formação do indivíduo, a socialização, o desenvolvimento e as descobertas, possibilitando a aprendizagem da criança.

As ações interdisciplinares com as histórias infantis viabilizam inúmeras possibilidades de práticas pedagógicas, com vivências de projetos com os conteúdos de matemática, língua portuguesa, música, história, artes dentre outros componentes curriculares, sucedendo na construção de novas ideias. Cabe ao professor o papel de criar condições pedagógicas e métodos dinâmicos e atraentes, proporcionando fácil compreensão e entendimento do que está sendo trabalhado (da Paz \& da Silva, 2020).

Em conformidade com da Cunha e Montoito (2020) o domínio linguístico é beneficiado pela literatura infantil, e como mediadora, expande a visão e a compreensão de mundo da criança. Como a matemática não possuí uma linguagem própria, a literatura exerce papel complementar para o seu entendimento, conduzindo para além da leitura de seus símbolos, técnicas e operações numéricas. Destarte, para que a aprendizagem da matemática ocorra é fundamental a compreensão linguística que a literatura possibilita para a compreensão dos problemas por parte das crianças. Outrossim, o professor ao utilizar a literatura infantil como aporte ao processo de ensino e aprendizagem da matemática, além de instigar a imaginação de seus alunos, insere o comportamento ativo e dinâmico, descaracterizando o ensino quando do comportamento passivo da criança (da Cunha \& Montoito, 2020).

Analogamente, Weissheimer e Montoito (2020) dissertam sobre o mesmo benefício da literatura para o aprendizado da geometria através de sua contribuição para o entendimento da noção do espaço pela criança, onde a união da geometria com a literatura infantil fornece a base necessária para o desenvolvimento das relações espaciais mais elementares. Em mesma direção, Silva (2020) reafirma o trabalho dos professores com a literatura infantil de forma planejada, com métodos diferenciados, visando além da formação, o resgate de valores, que ajudem a criança em sua socialização diante de conflitos de crescimento e espacialização que surgem no decorrer de seu desenvolvimento.

Os contos de fada, por exemplo, são gêneros narrativos essenciais que são trabalhados na escola, pelo fato de trazerem em suas narrativas elementos que envolvem a ficção, a magia e a fantasia, ocasionando na percepção de mundo da criança, o interesse pelo livro e aguçando sua curiosidade pela diversidade cultural, identitária, geográfica e temporal. Portanto, o contato entre as crianças e os textos literários infantis devem ocorrer o mais breve possível, principalmente em suas fases iniciais do desenvolvimento para iniciarem a relação amorosa entre a literatura e criança (Silva, 2020).

Hodiernamente, as escolas estão mais empenhadas com as práticas da contação de histórias dentro de suas atividades, com destaque no planejamento do professor, e convidando contadores de histórias para visitarem suas unidades (Silva, 2017). O professor possui capacidade para integrar a literatura em sua sala de aula, até porque a contação de histórias é tida como uma atividade pedagógica que traz encantamento, prazer e imaginação, não podendo ser separada do trabalho com os conteúdos curriculares. A prática de contação de histórias pode contribuir tanto para o ensino, como para a aprendizagem dos conteúdos escolares, não perdendo seu valor estético e artístico, contribuindo na aprendizagem significativa das crianças, pois de acordo com Silva (2017) estimula as crianças a imaginar, a criar e se envolver, enriquecendo o desenvolvimento de sua personalidade.

O professor de educação infantil dos anos iniciais deve apropriar-se de práticas pedagógicas que o auxiliem para executar atividades para as crianças, com a finalidade de seu desenvolvimento pleno. Atividades que estimulem a atenção em 
ouvir histórias são ótimas práticas pedagógicas para o desenvolvimento oral e enriquecimento de vocabulário da criança, além de ser um recurso para a formação do leitor, como também, quando chegar o seu momento de ser alfabetizada (Silva, 2017).

E neste sentido, a contação de histórias é uma prática pedagógica universal, onde professores ou educadores devem ter a consciência daquilo que transmitem. Como as diversidades de gêneros literários são bastante abrangentes, devem estar sempre atentos antes de iniciar uma história, observar a faixa etária e o significado que aquela história trará para as crianças de sua turma, proporcionando aos sons das palavras, a forma harmoniosa, conforme sua estrutura cerebral e suas necessidades de conhecimento para aquele determinado momento. (Paz \& da Silva, 2020).

Oliveira (2020) reforça a inserção das histórias infantis no planejamento das práticas pedagógicas nas escolas, resultando no sucesso em que referência ao desenvolvimento significativo da criança. E, as escolas cada vez mais vêm investindo nesse método construtivista que se encaixa perfeitamente na multidisciplinaridade. As histórias precisam ser planejadas, contadas e encantadas de modo a envolver a criança para se sentir transportada àquele cenário da narrativa, constituindo prazer em ouvir o enredo e assim estimulando sua área cognitiva. Por este motivo, que quando se reconta uma mesma história, mais interesse surge na criança para decifrar os códigos e começar a ler, a ideia é ensinar as crianças a pensar.

O professor pode ser um bom contador de histórias se possuir a capacidade de transformar as palavras contidas no livro em espetáculo, conseguindo trabalhar a comunicação, o diálogo, a atenção, a imaginação e a emoção, através do uso de algumas técnicas como gestos, tom de voz, expressão corporal, mímica, dança, enriquecendo ainda mais a narrativa e envolvendo seus alunos. Esse método construtivista possibilita a utilização de diversos recursos para se trabalhar em sala de aula.

Para Barone (2020) as histórias contadas também podem ser um recurso que proporcione a criança em lidar com as situações dolorosas da vida e desenvolver suas emoções. O professor que encontra em sua turma uma criança que esteja passando por um problema de natureza emocional, encontrará a difícil tarefa em ajudá-la o melhor possível, através da fantasia que as histórias trazem em si. Porém, nesses casos, a ação do professor deve ser em conjunto com a família, pois ambos têm um papel fundamental na construção do desenvolvimento infantil na totalidade.

Independente do ambiente, antes de iniciar a contação de histórias, o professor deve atentar-se à presença de elementos que sejam capazes de transformar o ambiente para a realização da atividade, ou seja, o ambiente deve ser preparado conforme o texto, assim como o professor ou o contador convidado devem estar preparados para desenvolverem a narrativa, os materiais também precisam estar organizados para que dessa forma as crianças sejam envolvidas durante a execução da atividade. O contador de histórias mais experiente nem sempre recorrerá ao livro para contá-las, porém, o livro trabalhado deverá sempre estar presente.

É importante mencionar que o modo como as histórias são apresentadas as crianças, precisa de cuidados, pois pode inibir a curiosidade, o interesse e o prazer em ouvi-las, tornando-se um desafio para quem vai contá-las, onde é preciso muita atenção em todos os detalhes para que a atividade tenha êxito em sua execução (Souza \& Francisco, 2017)

Cabe a ênfase de que a literatura desacorrenta a criança das fronteiras impostas pela realidade presente, possibilitando que busque saídas através da fantasia, para lidar com seus sentimentos, dificuldades e frustrações, por este motivo é uma importante ferramenta nas práticas pedagógicas (Micarello, 2018).

\section{Metodologia}

A Licenciatura em Pedagogia possibilita a inserção do futuro pedagogo (a) no âmbito das pesquisas, portanto, contribuindo à ciência em proposições à sociedade em geral, buscando soluções ou ensejando caminhos para o desenvolvimento da educação brasileira. Nesta perspectiva, o Trabalho de Conclusão de Curso constitui-se no primeiro 
momento científico do futuro profissional da educação, o que exige comprometimento, disciplina e dedicação ao seu desenvolvimento.

A pesquisa se enquadra como bibliográfica quanto ao tipo de coleta de dados (Menezes; Duarte; Carvalho \& Souza, 2019). Quanto a natureza, dados objetivos de caráter descritivo e analítico, se constitui como qualitativa e quantitativa (Mazo; Oliveira \& Tomazzoni, 2021). Ainda quanto sua natureza, pode-se compreender como método exploratório (Pereira et al., 2018).

Cabe incluir que a opção pelo tipo da metodologia como uma pesquisa bibliográfica pode ser entendida como o Estado da Arte. Pois, o caráter panorâmico desta pesquisa expõe as características de expressão crítica e analítica (Machado \& Ferreira, 2018). Dado que o Estado da Arte se constitui em duas abordagens, qualitativa quando de sua reflexão sobre o comportamento e evolução de uma área de conhecimento e, quantitativa quando agrupa numericamente um conjunto de produções científicas (dos Santos, 2020), podendo ainda ter os dados analisados pela evolução de uma área através de modelos matemáticos, a exemplo os modelos de regressão (Silva et al., 2021).

Buscando a ótica panorâmica sobre o tema, optou-se por avaliar as publicações cujo corpus se limitou, inicialmente, aos periódicos classificados como A (1, 2 e 3) e B (1, e 2), segundo a métrica utilizada pela Coordenação de Aperfeiçoamento de Pessoal de Nível Superior - CAPES, além de publicações em Anais, Livros, E-book, Teses, Dissertações e TCC's. Em que a coleta dos dados considerou o período de 2017 a 2021, utilizando-se da plataforma Google Acadêmico, objetivando recuperar no mínimo 20 produções nesta classificação.

Os primeiros achados contemplaram 16 periódicos com o corpus sobredito, e desta forma ampliamos nosso corpus para classificação, A (1, 2, 3 e 4) e B (1, 2 e 3), objetivando recuperar produções relacionadas ao temário mantendo o recorte temporal 2017 a 2021, resultando na composição do corpus com 23 publicações em periódicos, superando o objetivo inicial.

Para análise qualitativa dos dados optou-se pela seleção randomizada de 18 produções do corpus para sintetização e interpretação otimizadas, que versam em seus títulos, literatura infantil, educação infantil, prática, contos, educação e história, utilizando-se do recurso on line, no site WordArt.com, conhecido também como nuvem de palavras e, em virtude da recorrência, as palavras de maior frequência se destacam na nuvem.

Portanto, foram determinados sete passos que configuram o percurso metodológico adotado para pesquisa:

Passo 1 - Definição do eixo temático: desenvolvimento infantil, educação, primeira infância, histórias infantis, literatura infantil e práticas pedagógicas. Considerando como recorte temporal, o período de 2017 a 2021;

Passo 2 - Definição dos descritores: história infantil, educação, literatura infantil, prática, contos, contação de história, professor. Os descritores foram selecionados dada a experiência dos autores somada às práticas em pesquisas relacionadas ao temário;

Passo 3 - Identificação do Local dos bancos de dados, para acesso aos trabalhos completos, dado pelo corpus com periódicos classificados em A (1, 2, 3 e 4) e B (1, 2 e 3), sem a determinação do período da avaliação do Qualis/CAPES, ou seja, Google Acadêmico. Ocasião em que foram encontradas 98 produções;

Passo 4 - Realização da Leitura dos resumos: Seleção dos artigos considerando como critério de inclusão as produções relacionadas aos eixos temáticos e os termos dos títulos supraditos anteriormente, e como critério de exclusão 51 trabalhos por não terem relação com os eixos temáticos, bem como por não pertencerem à educação infantil;

Passo 5 - Realização da Leitura dos 23 artigos, 03 dissertações, 04 e-book, 02 trabalhos completos de anais, 03 livros e 12 trabalhos de conclusão de curso. Fichamentos e uso de planilha Excel para organização e análise, em que foram construídas as colunas com as seguintes informações: título; autor/ano; periódico; anais; e-book/ivro; documentos, localização geográfica do periódico (cidade e estado); qualis e plataforma de busca; 
Passo 6 - Organização e sistematização: estabelecendo as relações, quanto as divergências e convergências, categorizadas pelo temário motivado pela análise de conteúdo (Bardin, 2016);

Passo 7 - Análise dos dados: com abordagens acerca das possíveis lacunas e encaminhamentos.

Após conclusão dos passos 1 a 6, apresentam-se os resultados e discutem-se as produções científicas considerando duas perspectivas, por análise descritiva (tipo de publicação, ano, origem da produção, entre outros), e por abordagem qualitativa com análise interpretativa, motivo pelo qual se estabeleceu algumas categorias temáticas (prática pedagógica, contação de história, desenvolvimento infantil, literatura infantil e educação).

\section{Resultados e Discussão}

As produções científicas estão organizadas com informações gerais para análise descritiva, observando o título da publicação, autoria e ano, origem da produção e filiação, excluindo-se livro e e-book, observadas na Tabela 1.

Tabela 1 - Informações gerais das produções científicas recuperadas da plataforma Google Acadêmico conforme o corpus, do período de 2017-2021 em ordem decrescente.

\begin{tabular}{|c|c|c|c|}
\hline Título & Autor/Ano & Origem da Produção & Filiação \\
\hline $\begin{array}{c}\text { Análise bibliográfica e sistemática da literatura } \\
\text { acadêmica sobre "cidades inteligentes", "turismo" e } \\
\text { "competitividade". }\end{array}$ & Mazo et al. (2021) & $\begin{array}{l}\text { Turismo: Visão e } \\
\text { Ação }\end{array}$ & UAM e USP \\
\hline $\begin{array}{c}\text { Protagonismo Infantil na prática: O ensino } \\
\text { desenvolvido com a participação dos estudantes na } \\
\text { Educação Básica. } \\
\end{array}$ & $\begin{array}{c}\text { Schneider, Martins \& da Silva } \\
\text { (2021) }\end{array}$ & $\begin{array}{l}\text { Research, Society } \\
\text { and Development }\end{array}$ & $\begin{array}{l}\text { PROT. ASS. } \\
\text { PEDAG. E } \\
\text { UNIVATES }\end{array}$ \\
\hline $\begin{array}{c}\text { Analysis of sporotricose evolution using regression } \\
\text { model in cases of felines from Timbaúba / PE - } \\
\text { Brazil } \\
\end{array}$ & Silva et al. (2021) & $\begin{array}{l}\text { Research, Society } \\
\text { and Development }\end{array}$ & $\begin{array}{l}\text { UFRPE; UPE; } \\
\text { UFPE; UFPG }\end{array}$ \\
\hline A literatura na primeira infância & Barone (2020) & $\begin{array}{c}\text { Revista } \\
\text { psicopedagogia }\end{array}$ & UNIB \\
\hline $\begin{array}{l}\text { A atitude fenomenológica em Husserl e a prática } \\
\text { pedagógica }\end{array}$ & $\begin{array}{l}\text { Borges \& Rehbein } \\
(2020)\end{array}$ & $\begin{array}{c}\text { Cadernos de } \\
\text { Educação }\end{array}$ & PUCPR \\
\hline $\begin{array}{c}\text { Uma revisão sobre pesquisas brasileiras que } \\
\text { investigam as inter-relações entre Literatura Infantil } \\
\text { e Matemática }\end{array}$ & da Cunha \& Montoito (2020) & $\begin{array}{l}\text { Research, Society } \\
\text { and Development }\end{array}$ & IFSul \\
\hline $\begin{array}{c}\text { O enriquecimento do vocabulário dos estudantes } \\
\text { por meio da música em contos de fada no âmbito } \\
\text { das práticas pedagógicas dos professores da } \\
\text { educação básica. }\end{array}$ & da Paz \& da Silva (2020) & Dialogia & UPE; UPE \\
\hline $\begin{array}{c}\text { Leitura literária na educação infantil: mediação } \\
\text { docente e formação da criança leitora. }\end{array}$ & de Marco (2020) & Revista Interfaces & UNESP \\
\hline $\begin{array}{l}\text { Estado da arte: aspectos históricos e fundamentos } \\
\text { teórico-metodológicos. }\end{array}$ & dos Santos et al. (2020) & $\begin{array}{l}\text { Revista Pesquisa } \\
\text { Qualitativa }\end{array}$ & $\begin{array}{c}\text { UFPA e } \\
\text { SEMED-AP }\end{array}$ \\
\hline $\begin{array}{c}\text { O papel da literatura infantil no contexto da } \\
\text { educação infantil e na formação da criança: uma } \\
\text { revisão bibliográfica }\end{array}$ & $\begin{array}{l}\text { do Rosário Abreu \& } \\
\text { Gonçalves (2020) }\end{array}$ & $\begin{array}{l}\text { Research, Society } \\
\text { and Development }\end{array}$ & $\begin{array}{l}\text { UNIRIO e } \\
\text { CEFET-RJ. }\end{array}$ \\
\hline $\begin{array}{c}\text { (Des) interesse por escutar histórias: a fragmentação } \\
\text { dos nexos de significação e a importância do } \\
\text { contador. }\end{array}$ & $\begin{array}{l}\text { Souza, Archangelo \& de } \\
\text { Mendonça (2020) }\end{array}$ & $\begin{array}{l}\text { Nuances: estudos } \\
\text { sobre Educação }\end{array}$ & $\begin{array}{l}\text { UNIVAP; } \\
\text { UNICAMP e } \\
\text { Rede Mun/SP } \\
\end{array}$ \\
\hline $\begin{array}{l}\text { Literatura infantil e geometria: conexões possíveis } \\
\text { mapeadas pelo estado do conhecimento. }\end{array}$ & $\begin{array}{l}\text { Weissheimer \& Montoito } \\
\text { (2020) }\end{array}$ & $\begin{array}{l}\text { Research, Society } \\
\text { and Development }\end{array}$ & EMEF e IFSul \\
\hline $\begin{array}{l}\text { Um olhar psicopedagógico sobre a leitura na } \\
\text { primeira infância, prática significativa para a vida. }\end{array}$ & $\begin{array}{l}\text { da Silva Elias, da Silva \& } \\
\text { Coutinho (2019) }\end{array}$ & $\begin{array}{l}\text { Brazilian Journal of } \\
\text { Development }\end{array}$ & $\begin{array}{l}\text { Atenas College } \\
\text { University/EUA; } \\
\text { FACOL e } \\
\text { ALPHA } \\
\end{array}$ \\
\hline $\begin{array}{l}\text { Personagens de tiras cômicas: aquisição de } \\
\text { linguagem no humor e na ficção. }\end{array}$ & Gatti (2019) & $\begin{array}{c}\text { Alfa: Revista de } \\
\text { Linguística (São José }\end{array}$ & UFSCar \\
\hline
\end{tabular}




\begin{tabular}{|c|c|c|c|}
\hline & & do Rio Preto) & \\
\hline $\begin{array}{l}\text { Caminhos percorridos pela literatura infantil: uma } \\
\text { revisão bibliográfica. }\end{array}$ & $\begin{array}{c}\text { Vilela, Mariani Braz \& Silva } \\
(2019)\end{array}$ & Revista Letras Raras & $\begin{array}{c}\begin{array}{c}\text { Colégio Pedro II } \\
\text { e UFF }\end{array} \\
\end{array}$ \\
\hline $\begin{array}{c}\text { A representação do negro na literatura infantil } \\
\text { brasileira }\end{array}$ & Farias (2018) & Periferia & Colégio Pedro II \\
\hline $\begin{array}{c}\text { Educação integral e escola de tempo integral: } \\
\text { mapeamento da produção científica em periódicos } \\
\text { (2008 a 2017). }\end{array}$ & Machado \& Ferreira (2018) & Revista Exitus & UNICAMP \\
\hline $\begin{array}{l}\text { Literatura na educação infantil: pesquisa e formação } \\
\text { docente. }\end{array}$ & Micarello \& Baptista (2018) & Educar em Revista & UFJF \\
\hline $\begin{array}{c}\text { Formação de leitores: a dimensão afetiva na } \\
\text { mediação da família. }\end{array}$ & Orlando \& Leite (2018) & \begin{tabular}{|c|} 
Psicologia Escolar e \\
Educacional
\end{tabular} & UNICAMP \\
\hline $\begin{array}{c}\text { A formação de crianças leitoras: a família como } \\
\text { mediadora de leitura }\end{array}$ & $\begin{array}{c}\text { Balça, Azevedo \& Barros } \\
\text { (2017) }\end{array}$ & $\begin{array}{c}\text { Revista de educação } \\
\text { pública }\end{array}$ & UEv e UM \\
\hline $\begin{array}{c}\text { Biblioteca Escolar e Mediação da Leitura: estudo } \\
\text { sobre a importância da contação de história para a } \\
\text { formação do leitor } \\
\end{array}$ & $\begin{array}{l}\text { Da Silva, Alencar \& } \\
\text { Bernardino (2017) }\end{array}$ & Folha de Rosto & UFCA \\
\hline $\begin{array}{c}\text { Livros de histórias como recurso avaliativo e } \\
\text { promotor da compreensão dos estados mentais: uma } \\
\text { revisão. }\end{array}$ & Pelisson \& Rodrigues (2017) & $\begin{array}{c}\text { Gerais: Revista } \\
\text { Interinstitucional de } \\
\quad \text { Psicologia } \\
\end{array}$ & UFJF \\
\hline $\begin{array}{c}\text { Contação de histórias: um recurso pedagógico no } \\
\text { desenvolvimento da linguagem. }\end{array}$ & Souza \& Francisco (2017) & \begin{tabular}{|c|} 
Colloquium \\
Humanarum \\
\end{tabular} & UNOESTE \\
\hline $\begin{array}{c}\text { A tecnologia digital como ferramenta na } \\
\text { sensibilização para leitura no ensino fundamental. }\end{array}$ & Bencke (2020) & $T C C$ & IFSC \\
\hline $\begin{array}{c}\text { As contribuições da literatura infantil para o } \\
\text { desenvolvimento da leitura. }\end{array}$ & Porto (2019) & $T C C$ & UFMA \\
\hline $\begin{array}{c}\text { Como formar crianças leitoras? A importância da } \\
\text { literatura infantil na perspectiva de professoras da } \\
\text { educação infantil }\end{array}$ & Fagundes (2018) & $T C C$ & UNIPAMPA \\
\hline $\begin{array}{c}\text { A formação dos conceitos científicos nos anos } \\
\text { iniciais do ensino fundamental: uma proposta para o } \\
\text { Ensino de Ciências Naturais usando literatura } \\
\text { infantil amazonense } \\
\end{array}$ & da Silva (2020) & Dissertação & UEA \\
\hline $\begin{array}{c}\text { A literatura infantil no processo de formação da } \\
\text { criança leitora: a experiência no projeto LeiA }\end{array}$ & Lima (2019) & $T C C$ & UNB \\
\hline $\begin{array}{c}\text { Nas páginas do jornal "Correio Braziliense": os } \\
\text { espaços de contação de história (DF/2019) }\end{array}$ & Mendonça (2019) & $T C C$ & UNB \\
\hline $\begin{array}{l}\text { A importância do professor de educação infantil } \\
\text { para desenvolver a fantasia por meio da literatura } \\
\text { infantil. }\end{array}$ & Moreira (2018) & $T C C$ & UTFPR \\
\hline $\begin{array}{l}\text { A leitura na educação infantil: contribuições } \\
\text { docentes na formação leitora das crianças. }\end{array}$ & Oliveira (2021) & $T C C$ & UFPB \\
\hline $\begin{array}{l}\text { A contação de histórias para crianças da educação } \\
\text { infantil }\end{array}$ & Oliveira (2020) & $T C C$ & PUCGIÁS \\
\hline A importância das histórias no Pré-Escolar & Pimentel (2017) & Dissertação & ESEC -PT \\
\hline $\begin{array}{c}\text { Literatura infantil: uma prática estratégica para o } \\
\text { desenvolvimento cognitivo e mediadora da } \\
\text { aprendizagem. }\end{array}$ & Queiroz (2017) & Dissertação & UFP-PT \\
\hline $\begin{array}{c}\text { Literatura infantil na sala de aula: possibilidades de } \\
\text { desenvolver a oralidade através dos contos e } \\
\text { recontos de histórias. }\end{array}$ & Rocha (2019) & $T C C$ & UFPB \\
\hline $\begin{array}{c}\text { A importância da contação de história na educação } \\
\text { infantil. }\end{array}$ & Silva (2017) & $T C C$ & UFPB \\
\hline $\begin{array}{c}\text { A contribuição dos contos de fadas nas práticas } \\
\text { pedagógicas do professor das séries iniciais do } \\
\text { ensino fundamental }\end{array}$ & Silva (2020) & $T C C$ & UFOP \\
\hline A formação da criança leitora: textos literários & Steiner et al. (2018) & $T C C$ & UFSC \\
\hline $\begin{array}{c}\text { Adaptações literárias de clássicos: a importância da } \\
\text { relação entre texto e imagem para a formação de } \\
\text { leitores }\end{array}$ & $\begin{array}{l}\text { Neres \& Lacerda } \\
\quad(2017)\end{array}$ & $\begin{array}{l}\text { Anais - XII Jogo do } \\
\text { Livro e II Seminário } \\
\text { Internacional Latino- }\end{array}$ & UFF \\
\hline
\end{tabular}




\begin{tabular}{|c|c|c|c|}
\hline & & Americano & \\
\hline A tecnologia na educação infantil & Souza (2019) & $\begin{array}{c}\text { Anais - VII } \\
\text { Seminário Nacional } \\
\text { e III Seminário } \\
\text { Internacional, } \\
\text { Políticas Públicas, } \\
\text { Gestão e Práxis } \\
\text { Educacional }\end{array}$ & UNIASSELVI \\
\hline
\end{tabular}

Fonte: Autores (2021)

Na Tabela 1, os periódicos selecionados seguem a classificação Qualis/Capes distribuídos em 04 (A1), 01 (A2), 05 (A3), 02 (A4), 04 (B1), 05 (B2) e 02 (B3). Dentre os documentos têm-se trabalhos de conclusão de curso, sendo 02 em pósgraduação e 10 em graduação, seguidos de 03 dissertações ao nível de mestrado, respectivamente na área de educação e 02 publicações em Anais. Na Figura 1 demonstra-se a distribuição espacial e longitudinal em produção por estado, agrupamento regional e quantidade por ano.

Figura 1 - Distribuição espacial e longitudinal das publicações selecionadas e recuperadas da plataforma Google Acadêmico conforme o corpus, do período de 2017-2021.
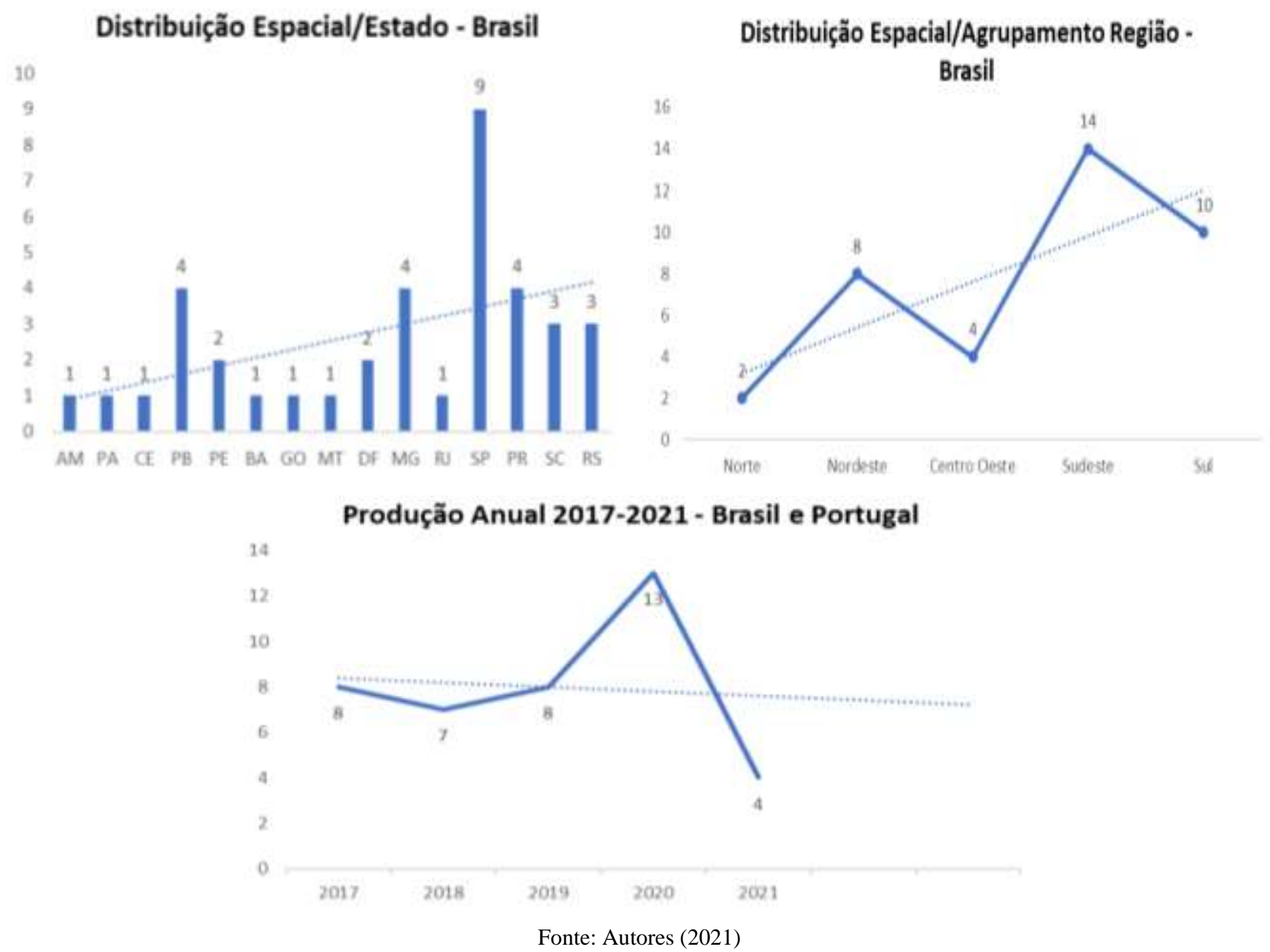

Observa-se na Figura 1, a distribuição espacial por estados e agrupamento por regiões, considerando a sequência norte, nordeste, centro oeste, sudeste e sul. Para produção anual inclui-se dois manuscritos selecionados de Portugal (2017). 
A Região Norte contribuiu com uma dissertação e um manuscrito nos eixos, literatura infantil e educação, respectivamente. Com a Região Nordeste foram selecionadas três TCC e cinco manuscritos nos eixos, história infantil, literatura infantil, prática pedagógica e educação. Na Região Centro Oeste foi possível obter três TCC e um manuscrito com abordagens aos eixos, literatura infantil, história infantil e educação. Para a Região Sudeste foram selecionados dois TCC e doze manuscritos referentes aos eixos, primeira infância, educação, literatura infantil, história infantil e prática pedagógica. Por fim, na Região Sul obteve-se quatro TCC e seis manuscritos referentes aos eixos, educação, prática pedagógica, literatura infantil, primeira infância e história infantil.

É possível considerar uma perspectiva de suave tendência ao crescimento de publicações, ao nível estadual, na área de educação infantil no tocante ao desenvolvimento da criança e uso de histórias infantis como alternativa pedagógica. A tendência é ascendente da Região Norte em direção a Região Sudeste, e desta para a Região Sul, neste corpus, apresenta-se em queda de $28 \%$. Por outro lado, infere-se a tendência decrescente, considerando a espacialidade temporal. Contudo, deve-se perceber no recorte do corpus limitação ao seu fechamento, visto que determinado o fim em 2021, cujas produções se limitam aos cinco primeiros meses do ano.

Não obstante, destacar que Paraíba, Paraná e Minas Gerais estão igualados em quantidade de publicações, ambos com 4 publicações, seguidos por Santa Catarina e Rio Grande do Sul com três publicações respectivamente e Distrito Federal com Pernambuco contendo duas publicações cada. Tendo os demais estados apenas uma publicação, excetuando São Paulo que assume o lugar de liderança absoluta com nove publicações, totalizando 38 publicações selecionadas no âmbito nacional, somando-se dois manuscritos no âmbito internacional (Portugal), constituindo o corpus em 40 publicações.

No contexto da análise qualitativa, estabeleceram-se as categorias temáticas, prática pedagógica, contos, história, desenvolvimento infantil, literatura infantil, educação e educação infantil, para uma sistematização e interpretação das abordagens. Estas categorias foram subsidiadas pela seleção aleatória de 18 produções, distribuídas em: 2 dissertações (Internacionais), 11 artigos de periódicos classificados (A1=2; A2 =1; A3=4; B1=2; B2=2) e 5 TCC's.

A Figura 2 demonstra os termos mais relevantes encontrados nos títulos dos artigos que formaram base para construção das categorias supraditas e seleção randomizada para análise interpretativa. 
Figura 2 - Nuvens de palavras originárias a partir dos títulos dos artigos selecionados e indexados ao Google Acadêmico, considerando o período de 2017-2021.

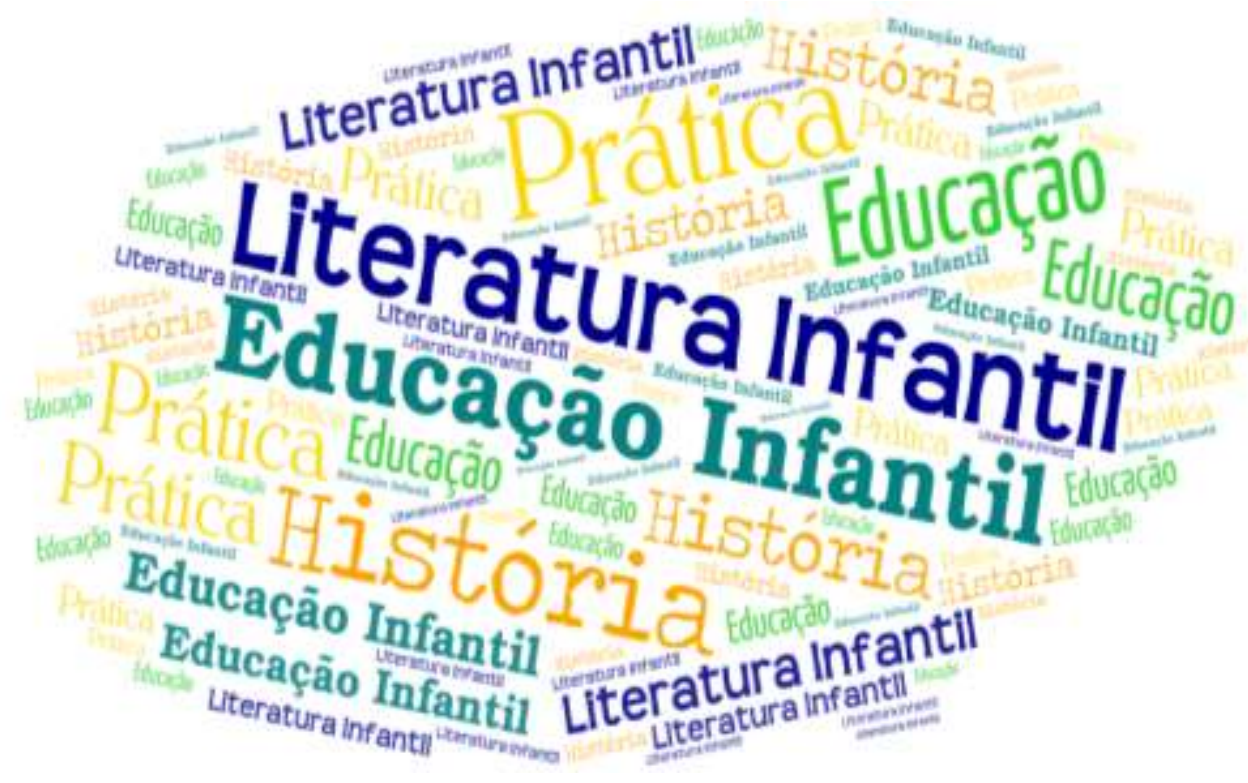

Fonte: site WordArt.com

Observa-se na Figura 2 que o termo literatura infantil se constituiu em maior relevância, dada sua recorrência nos títulos dos artigos pesquisados, seguido dos termos educação infantil, história, prática e educação.

Considerando o desenvolvimento infantil são discutidas e abordadas questões relacionadas à prática da leitura para construção de hábito, as competências sociocognitivas e as emoções podem ser incentivas com o uso de livros de histórias (Pelisson \& Rodriguez, 2017). A mediação da leitura se faz não apenas com livros, visto que a participação familiar no processo de desenvolvimento é parte indissociável (Balça; Azevedo \& Barros, 2017).

Com o uso de práticas lúdicas, as histórias infantis contribuem em registros subconscientes de uma infinidade de emoções (Barone, 2020). Posto isso, cabe verificar na observância do desenvolvimento social e interacional da criança, características que evidenciem o aperfeiçoamento da linguagem, o pensamento e a imaginação da criança. A criança deve ser entendida como ser completo, dado que a considerar como um adulto em miniatura, caracteriza conduta inconcebível. Nesta perspectiva os estudos de Porto (2019) reforçam o uso da literatura infantil como parte indissociável ao desenvolvimento cognitivo da criança.

Quanto as práticas pedagógicas a pesquisa de Borges e Rehbein (2020) firma-se na perspectiva fenomenológica de Hurssel, em que consiste verificar o papel do professor cujas práticas consideram compreender e interagir no universo infantil ressignificando o potencial desenvolvimento da criança através da fantasia. Desta forma, a descontextualização da conduta natural e fenomenológica sob o olhar do professor ao entendimento do construtivismo como aprendizagem significativa não se negligencia.

A formação do professor está evidenciada pelo alicerce que se revelará em atitudes quando do exercício da profissão, nos estudos de Micarello e Baptista (2018), em que o bom planejamento didático requer conhecimentos aprofundados da realidade do contexto escolar. E a construção de métodos e alternativas propostas ao desenvolvimento significativo da criança na educação infantil, pode ter como instrumentos às práticas pedagógicas o uso de literaturas correlacionadas ao contexto da criança. Cabe lembrar que a promoção e desenvolvimento de alternativas pedagógicas é essencial para Schneider, Martins e da Silva (2021), quando do entendimento que as crianças naturalmente são inquietas, e buscam descobrir o mundo ao seu redor. Dado que este processo de descoberta requer direcionamento e mediação do professor. 
A literatura infantil abordada nas práticas pedagógicas supera o entendimento de ludicidade (Moreira, 2018) e na perspectiva do prazer em ler, dado que a leitura significativa apropria-se do prazer da leitura e intensifica o domínio linguístico, da Cunha e Montoito (2020) consideram que o estabelecimento mediado para descoberta contribui para compreensão de mundo. Motivo pelo qual surge a inserção de novos conteúdos, como a matemática, onde a literatura supera símbolos e operações numéricas.

No mesmo sentido, da Paz e da Silva (2020) reforçam a responsabilidade do professor na criação das condições pedagógicas e metodológicas de caráter dinâmico, ao passo que atrativo, facilitando compreensão e entendimento da atividade proposta. As inserções interdisciplinares favorecem ao processo de aprendizagem. Onde, matemática, história, música, artes, entre outros componentes, devem ser considerados como condições viáveis e indispensáveis.

Considerando as categorias, contos, histórias e literatura infantil, observa-se que a expressão cultural retratada nos contos, recontos e reescritas também contribui para a compreensão, a aceitação das emoções, conhecer seu lugar social, estabelecer vínculos e relações com outras pessoas. Do mesmo modo, nos estudos realizados por Rocha (2019) e Silva (2020) reforçam a utilização dos contos de fadas no ambiente familiar e escolar para auxiliar as crianças na superação de alguns conflitos, inseguranças e medos. Desde que se estimule o protagonismo da criança, visto que os sentimentos presentes nos contos de fadas representam as sensações próprias.

Diante do papel da escola e da família na promoção e constituição de hábitos de leitura, Pimentel (2017) salienta que a exploração de histórias possibilita às crianças um olhar positivo para o livro, como um objeto que lhes pode proporcionar momentos de prazer, divertimento e conhecimento, ao invés de o verem como uma obrigação. Estes comportamentos são possíveis mediante o significado retratado pelas crianças.

Percebe-se que as crianças gostam de ouvir história, e com mediação do professor é possível associa-la ao aprendizado dinâmico e interativo. Neste aspecto Rocha (2019) ressalta a contação de histórias como proposta para possibilidades de aprendizagem, em que o conhecimento seja construído com criatividade por meio da ludicidade, onde as aulas tendem a deixar de ser cansativas.

Não obstante, lembrar que a literatura infantil constitui-se em um meio eficiente na promoção do desenvolvimento de competências e habilidades comunicativas e intelectuais. Queiroz (2017) ressalta a importância da leitura de histórias infantis como estratégia para o desenvolvimento cognitivo e como mediadora da aprendizagem. Logo, pode-se inferir que a imaginação e a criatividade das crianças são fortes contributos a serem explorados através de estratégias de leituras à formação da criança (do Rosário Abreu \& Gonçalves, 2020).

Outrossim, os achados de Fagundes (2018) para a literatura infantil, confirmam ser eficientes e eficazes no desenvolvimento da criança, além de necessário aos professores que devem compreender e conhecer as características individuais das crianças. Observando que a construção do pensamento percorre por abordagens pedagógicas baseadas na epistemologia (Weissheiner \& Montoito, 2020), somando-se a eficiência o caráter da interdisciplinaridade.

Por fim, as categorias educação e educação infantil é possível refletir que nas escolas de educação infantil, nos apontamentos em de Marco (2020), o processo de formação da criança visando a valorização da literatura infantil no processo de humanização é condição indispensável. Tem-se a intenção de formar leitores mais plurais e críticos com formas de produção artística no uso da palavra. Desde que se inicie com um planejamento direcionado às interlocuções, através da valorização e utilização das vivências pessoais e coletivas da criança no ambiente escolar.

Os contatos iniciais das crianças com a escrita e a leitura representam os primeiros passos para construção do conhecimento e descobertas do mundo em seu redor. Educação Infantil ocorre com as práticas e Oliveira (2021) expõe a necessidade de práticas construídas pela mediação do professor na constituição do ser, relacional, cognitivo, social, motor e leitor. A Escola tem papel fundamental no processo e sua ocorrência é resultado do trabalho conjunto dos atores envolvidos em 
todos os segmentos da escola. Isto por que, compreende-se que a educação é um direito constitucional e fundamental na transformação do ser humano, conquistado e é fundamental na transformação do homem e da sociedade.

\section{Conclusão}

O desenvolvimento infantil na educação da primeira infância é a porta de entrada para experimentações, descobertas e sentimentos para que a criança aproveite todo seu potencial. Diante as impressões apresentadas nesta pesquisa, constataram-se os direcionamentos positivos dos autores em relação ao desenvolvimento sociocognitivo e emocional da criança a partir das histórias infantis, tanto no ambiente escolar quanto no ambiente familiar, compondo em importante ferramenta pedagógica.

A pesquisa bibliográfica, de natureza qualitativa e quantitativa, demostrou-se relevante na perspectiva de enfoque no Estado da Arte. Pois, com a reflexão da literatura infantil pode-se observar tendência de crescimento em meio científico no corpus supradito, o que revela-se na observância do resgate ou aprimoramento genuínos do prazer de ler, do imaginário e da curiosidade infantil em sua compreensão de mundo através das histórias, de forma divertida e chamando a sua atenção em conjunto com a construção de sua formação emocional, social e cognitiva.

$\mathrm{O}$ enfoque adotado mostrou-se consistente e atendeu ao objetivo da pesquisa, permitindo o entender acerca da importância de práticas lúdicas quanto ao uso das histórias infantis como práticas pedagógicas, abrangendo as múltiplas linguagens através de projetos literários que respeitam a criança e sua infância, como um ser em desenvolvimento e dinâmico, em constantes mudanças de forma gradual e particular. Bem como proporcionou a constatação de que a família reside como fonte balizadora e indissociável, complementar às práticas pedagógicas.

Acredita-se que este estudo alicerçou um conjunto de informações para produzir novas pesquisas. Que contribua de forma significativa, ao envolvimento de novos olhares subsidiando questionamentos e ampliando as reflexões acerca dos benefícios que a contação de histórias infantis, na primeira infância, reside em prática pedagógica alternativa.

Recomenda-se, portanto, que se produzam estudos aprofundados sobre o tema e abordem outras técnicas que podem ser utilizadas de forma lúdica para a inserção de livros na vida das crianças, assim como também abordem benefícios ao desenvolvimento cognitivo da criança, considerando os tempos atuais.

\section{Agradecimentos}

A Universidade Paulista - UNIP, Recife/Pernambuco; à Coordenação de Aperfeiçoamento de Pessoal de Nível Superior-CAPES.

\section{Referências}

Balça, Â. M. F. M. D. P., Azevedo, F., \& Barros, L. M. F. R. (2017). A formação de crianças leitoras: a família como mediadora de leitura. Revista de educação pública, 26, 713-727.

Bardin, L. (2016). Análise de Conteúdo. Edição Revista e ampliada. Edições 70.

Barone, L. M. C. (2020). A literatura na primeira infância. Revista Psicopedagogia, 37(113), 225-231. http://dx.doi.org/10.5935/0103-8486.20200020

Bencke, B. D. D. O. D. (2020). A tecnologia digital como ferramenta na sensibilização para leitura no ensino fundamental. Trabalho de Conclusão de Curso (Especialização em Pesquisa e Prática Pedagógica) - Instituto Federal de Santa Catarina, Santa Catarina, 20. https://repositorio.ifsc.edu.br

Borges, V., \& Rehbein, L. (2020). A atitude fenomenológica em Husserl e a prática pedagógica. Cadernos de Educação, (63), 123-136. https://doi.org/10.15210/caduc.v0i63.17224

Brandão, A. C. P., \& de Sousa Rosa, E. C. (2017). Ler e escrever na Educação Infantil: discutindo práticas pedagógicas. Autêntica. E-book [8-20]. https://books.google.com.br/books?hl=pt-BR\&lr=\&id=P_qwDgAAQBAJ\&oi=fnd\&pg=PT7\&dq=BRAND\%C3\%830

Cademartori, L. (2017). O que é literatura infantil. Brasiliense. E-book [4]. https://books.google.com.br/books?hl=pt 
da Cunha, A. V., \& Montoito, R. (2020). Uma revisão sobre pesquisas brasileiras que investigam as inter-relações entre Literatura Infantil e Matemática. Research, Society and Development, 9(9), e462997496-e462997496.

da Paz, A. M. A., \& da Silva, M. D. F. G. (2020). O enriquecimento do vocabulário dos estudantes por meio da música em contos de fada no âmbito das práticas pedagógicas dos professores da educação básica. Dialogia, (36), 428-440. https://doi.org/10.5585/dialogia.n36.16791

da Silva Elias, M. C. C., da Silva, C. S., \& Coutinho, D. J. G. (2019). Um olhar psicopedagógico sobre a leitura na primeira infância, prática significativa para a vida. Brazilian Journal of Development, 5(12), 31116-31128. https://doi.org/10.34117/bjdv5n12-214

da Silva, A. J. M., Alencar, A. Q., \& Bernardino, M. C. R. (2017). Biblioteca Escolar e Mediação da Leitura: estudo sobre a importância da contação de história para a formação do leitor. Folha de Rosto, 3(Especial), 36-44. https://periodicos.ufca.edu.br/ojs/index.php/folhaderosto/issue/view/15

de Marco, M. T. (2020). Leitura literária na educação infantil: mediação docente e formação da criança leitora. Revista Interfaces, 11(02), 171-183. $10.5935 / 2179-0027.20200030$.

do Rosário Abreu, D., \& Gonçalves, R. M. (2020). O papel da literatura infantil no contexto da educação infantil e na formação da criança: uma revisão bibliográfica. Research, Society and Development, 9(5), e66953078-e66953078. http://dx.doi.org/10.33448/rsd-v9i5.3078

dos Santos, M. A. R., dos Santos, C. A. F., Serique, N. P., \& Lima, R. R. (2020). Estado da arte: aspectos históricos e fundamentos teóricometodológicos. Revista Pesquisa Qualitativa, 8(17), 202-220. http://dx.doi.org/10.33361/RPQ.2020.v.8.n.17.215

Fagundes, M. M. (2018). Como formar crianças leitoras? a importância da literatura infantil na perspectiva de professoras da educação infantil. Trabalho de Conclusão de Curso (Licenciatura em Pedagogia) - Universidade Federal do Pampa, Campus Jaguarão. Jaguarão, 22.2018. http://dspace.unipampa.edu.br:8080/jspui/handle/riu/3347

Farias, J. O. (2018). A representação do negro na literatura infantil brasileira. Periferia, 10(1), 17-32. 10.12957/periferia.2018.27988.

Flôres, O. C., \& Gabriel, R. (2020). O que precisamos saber sobre a aprendizagem da leitura: contribuições interdisciplinares. Fundação de Apoio a Tecnologia e Ciencia-Editora UFSM. https://books.google.com.br/books?hl=pt

Gatti, M. A. (2019). Personagens de tiras cômicas: aquisição de linguagem no humor e na ficção. Alfa: Revista de Linguística (São José do Rio Preto), 63(1), 113-132. https://doi.org/10.1590/1981-5794-1904-5

Lima, K. A. D. (2019). A literatura infantil no processo de formação da criança leitora: a experiência no projeto LeiA. Trabalho de Conclusão de Curso (Licenciatura em Pedagogia) - Universidade de Brasília, Brasília, 81 f., il. https://bdm.unb.br/handle/10483/22702

Machado, C., \& Ferreira, L. R. (2018). Educação integral e escola de tempo integral: mapeamento da produção científica em periódicos (2008 a 2017). Revista Exitus, 8(3), 87-112. 10.24065/2237-9460.2018v8n3ID640

Mazo, A., Oliveira, R. K. D., \& Tomazzoni, E. L. (2021). Análisis bibliográfica y sistemática de la literatura académica de los términos "ciudades inteligentes", "turismo" y “competitividad". Turismo: Visão e Ação, 23(1), 148-168. https://doi.org/10.14210/rtva.v23n1.p148-168

Mendonça, L. T. D. (2019). Nas páginas do jornal "Correio Braziliense": os espaços de contação de história (DF/2019). Trabalho de Conclusão de Curso (Licenciatura em Pedagogia) — Universidade de Brasília, Brasília, 64. 2019.

Menezes, A. H. N., Duarte, F. R., Carvalho, L. O. R., \& Souza, T. E. S. (2019). Metodologia científica: teoria e aplicação na educação a distância. Universidade Federal do Vale do São Francisco, Petrolina-PE. e-book, 83p.

Micarello, H., \& Baptista, M. C. (2018). Literatura na educação infantil: pesquisa e formação docente. Educar em Revista,34(72), 169-186. http://dx.doi.org/10.1590/0104-4060.62731

Moreira, L. A. C. (2018). A Importância do professor de educação infantil para desenvolver a fantasia por meio da literatura infantil. Trabalho de Conclusão de Curso (Especialização em Ensino de Língua Portuguesa e Literatura) - Universidade Tecnológica Federal do Paraná, Curitiba, 40. http://repositorio.roca.utfpr.edu.br/jspui/handle/1/13216

Nascimento, D. L. D., \& Farias, G. A. D. (2019). Histórias infantis: a influência das histórias infantis na educação das crianças no Brasil. São Paulo: Pontes Editores, 2019, 159-170. http://www.repositorio.ufc.br/handle/riufc/48251

Neres, G. O., \& Lacerda, M. G. (2017). Adaptações literárias de clássicos: a importância da relação entre texto e imagem para a formação de leitores. XII Jogo do Livro e II Seminário Internacional Latino-Americano. Universidade Federal de Minas Gerais, Faculdade de Educação, Belo Horizonte, 17. http://www.ceale.fae.ufmg.br/app/webroot/files/uploads/xii\%20jogo\%20do\%20livro/ANAIS\%20parte\%201/ADAPTA\%C3\%87\%C3\%95ES\%20LITER\%C3 $\% 81$ RIAS $\% 20$ DE $\% 20$ CL $\%$ C3\%81SSICOS.pdf

Oliveira, L. F. D. (2021). A leitura na educação infantil: contribuições docentes na formação leitora das crianças. Trabalho de Conclusão de Curso (Licenciatura em Pedagogia - Modalidade à Distância) - Universidade Federal da Paraíba, Centro de Educação. João Pessoa, 44. https://repositorio.ufpb.br/jspui/handle/123456789/19346

Oliveira, M. S. (2020). A contação de histórias para crianças da educação infantil. Trabalho de Conclusão de Curso (Licenciatura em Pedagogia) - Pontifícia Universidade Católica de Goiás, Goiás, 46. 2020.

Orlando, I. R., \& Leite, S. A. D. S. (2018). Formação de leitores: a dimensão afetiva na mediação da família. Psicologia Escolar e Educacional, 22(3), 511518. https://doi.org/10.1590/2175-35392018039282

Pelisson, M. C. C., \& Rodrigues, M. C. (2017). Livros de histórias como recurso avaliativo e promotor da compreensão dos estados mentais: Uma revisão. Gerais: Revista Interinstitucional de Psicología, 10(1), 81-94. http://pepsic.bvsalud.org/pdf/gerais/v10n1/09.pdf 
Pereira, A. S. et al. (2018). Metodologia da pesquisa científica. UFSM. https://repositorio. ufsm. br/bitstream/handle/1/15824/Lic_Computacao_MetodologiaPesquisa-Cientifica. pdf.

Pimentel, J. H. A. (2017). A importância das histórias no Pré-Escolar (Doctoral dissertation). Escola Superior de Educação, Instituto Politécnico de Coimbra. Coimbra, 67. http://hdl.handle.net/10400.26/23129

Porto, A. G. (2019). As contribuições da literatura infantil para o desenvolvimento da leitura. Monografia do curso de licenciatura interdisciplinar em línguas e códigos, habilitação em língua portuguesa. Universidade Federal do Maranhão, 48. http://hdl.handle.net/123456789/3126

Queiroz, T. G. D. (2017). Literatura infantil: uma prática estratégica para o desenvolvimento cognitivo e mediadora da aprendizagem (Doctoral dissertation). Universidade Fernando Pessoa, Faculdade de Ciências Humanas e Sociais. Porto, 95. http://hdl.handle.net/10284/6328

Rocha, C. F. D. A. (2019). Literatura infantil na sala de aula: possibilidades de desenvolver a oralidade através dos contos e recontos de histórias. Trabalho de Conclusão de Curso (Licenciatura em Pedagogia) - Universidade Federal da Paraíba, Centro de Educação. João Pessoa, 101. https://repositorio.ufpb.br/jspui/handle/123456789/16337

Schneider, M. C., Martins, S. N., \& da Silva, J. S. Protagonismo Infantil na prática: O ensino desenvolvido com a participação dos estud antes na Educação Básica. Research, Society and Development, 10(1), e14910111574-e14910111574. http://dx.doi.org/10.33448/rsd-v10i1.11574

Silva, F. M. D. S. V. (2017). A importância da contação de história na educação infantil. Trabalho de Conclusão de Curso (Licenciatura em Pedagogia Modalidade à Distância) - Universidade Federal da Paraíba, Centro de Educação. Coremas, 40.2017. https://repositorio.ufpb.br/jspui/handle/123456789/4094

Silva, J. E., Cirino, M. D. de A. Farias, E. F. de, Fonseca, L. F. da, Shinohara, G. M., Shinohara, N. K. S., \& Cunha Filho, M. (2021). Analysis of sporotricose evolution using regression model in cases of felines from Timbaúba / PE - Brazil. Research, Society and Development, 10(1), e51310112082. https://doi.org/10.33448/rsd-v10i1.12082

Silva, M. D. L. G. D. (2020). A formação dos conceitos científicos nos anos iniciais do ensino fundamental: uma proposta para o Ensino de Ciências Naturais usando literatura infantil amazonense. Dissertação (Programa de Pós-Graduação em Educação e Ensino de Ciências na Amazônia) - Universidade do Estado do Amazonas, Manaus, 135. http://repositorioinstitucional.uea.edu.br//handle/riuea/2629

Silva, S. E. B. D. (2020). A contribuição dos contos de fadas nas práticas pedagógicas do professor das séries iniciais do en sino fundamental. Trabalho de Conclusão de Curso (Licenciatura em Pedagogia) - Universidade Federal de Ouro Preto, Instituto de Ciências Humanas e Sociais, Departamento de Educação. Mariana, 25. http://www.monografias.ufop.br/handle/35400000/2912

Souza, A. M., \& Francisco, O. B. (2017). Contação De Historias: Um Recurso Pedagógico No Desenvolvimento Da Linguagem. In Colloquium Humanarum. ISSN: 1809-8207 14(1), 40-51. 10.5747/ch.2017.v14.n1.h292

Souza, S. M. S. (2019). A tecnologia na educação infantil. Seminário (VII Seminário Nacional e III Seminário Internacional, Políticas Públicas, Gestão e Práxis Educacional) - Universidade do Sudoeste da Bahia, Programa de Pós-Graduação em Educação. Uniasselvi. Vitória da conquista, 7(7), 1581-1591. https://core.ac.uk/download/pdf/229302292.pdf

Souza, S., Archangelo, A., \& de Mendonça, L. C. (2020). (Des) interesse por escutar histórias: a fragmentação dos nexos de significação e a importância do contador. Nuances: estudos sobre Educação, 31,345-357. 10.32930/nuances.v31i0.8331

Steiner, G. F. (2018). A formação da criança leitora: textos literários. Trabalho de Conclusão de Curso (Graduação em Pedagogia) - Universidade Federal de Santa Catarina, Centro de Ciências da Educação. Florianópolis, 49. https://repositorio.ufsc.br/handle/123456789/196286

Vilela, L. P., Braz, R. M. M., \& de Mello, D. (2019). Caminhos percorridos pela literatura infantil: uma revisão bibliográfica. Revista Letras Raras, 8(4), 201216. http://dx.doi.org/10.35572/rlr.v8i4.1381

Weissheimer, R. F., \& Montoito, R. (2020). Literatura infantil e geometria: conexões possíveis mapeadas pelo estado do conhecimento. Research, Society and Development, 9(9), e245997178-e245997178. http://dx.doi.org/10.33448/rsd-v9i9.7178 